\title{
The influence of education level on choosing coastal regions as tourist destinations
}

\author{
Lukrecija DjeriA, Sanja BožićA, Predrag Stamenković ${ }^{A}$, Imre Nagy ${ }^{A}$ \\ Received: October 20, 2016 | Revised: April 20, 2017 | Accepted: May 18, 2017
}

DOI: 10.18421/GP21.02-03

\begin{abstract}
The main aim of the paper is to investigate the influence of formal education level on decision-making process when choosing a tourist destination based on multivariate analysis of variance (MANOVA). The survey was conducted on the sample of 252 respondents from Bačka region (Vojvodina/Serbia). Also, this study strives to examine the influence of education level on decision-making process including all five phases of decision-making process: need awareness, information search, alternatives estimation, purchase and purchase evaluation, applied to the process of choosing coastal regions as tourist destinations. The study shows that education level is related to four out of five phases of decision-making process (only in case of need awarness there is no statisticaly significant difference). This is especially important for creation of a marketing platform with promotional acitivities adjasted to different market segments diferentiated by education level. Moreover, the study discusses differences in behaviour of diffrent educational groups while choosing travel destinations.
\end{abstract}

Keywords: consumer behavior, decision making, education level, Serbia

\section{Introduction}

Achieving success on travel market depends mainly on the knowledge of the characteristics of potential tourists, their needs and motivations, behaviors in the decisions making process about the choice of tourist destination as well as the factors that affect that behavior.

A research on potential tourist behavior is important for companies in tourism field in order to create value and adequately communicate with users about their tourist products and services. That is why research on tourist behaviour and decision-making is critical to business success of every company on the tourist market and thus the first researches on the topic of decision making represent the cornerstone in marketing and consumer behavior.

One of the most important segments of the research regarding customers behavior in tourism is the process of decision making about a tourist desti- nation (Djeri, et al., 2007). Tourist's decision-making processes are complex; involve a wide array of single decisions from deciding 'where to go' through 'what are we going to do now we're here' and beyond. Many choices are based on contextual 'facts'. Many more are based on perceptions of relatively high-risk decisions judgments, that is, no-one knows how 'good' their holiday is going to be until they are experiencing it (Smallman, Moore, 2009; Marion, 2016).

It is evident that geospace, with its natural and cultural values, is a significant resource in tourism industry (Ćopić, et al., 2014; Kasagranda, et al., 2016). This also refers to coastal regions as important parts of destinations' natural values. This study aims to analyse the influence of formal education level of tourists on the process of choosing coastal regions as tourist destination by applying the classical model of "decisionmaking process". This model treats a potential tourist as a person who, by making a decision about a tour-

\footnotetext{
A Department of Geography, Tourism and Hotel Management, Faculty of Sciences, University of Novi Sad, Trg Dositeja Obradovića 3, 21000 Novi Sad, Serbia

* Corresponding author: Sanja Božić, email: e-mail:sanja.bozic.89@gmail.com
} 


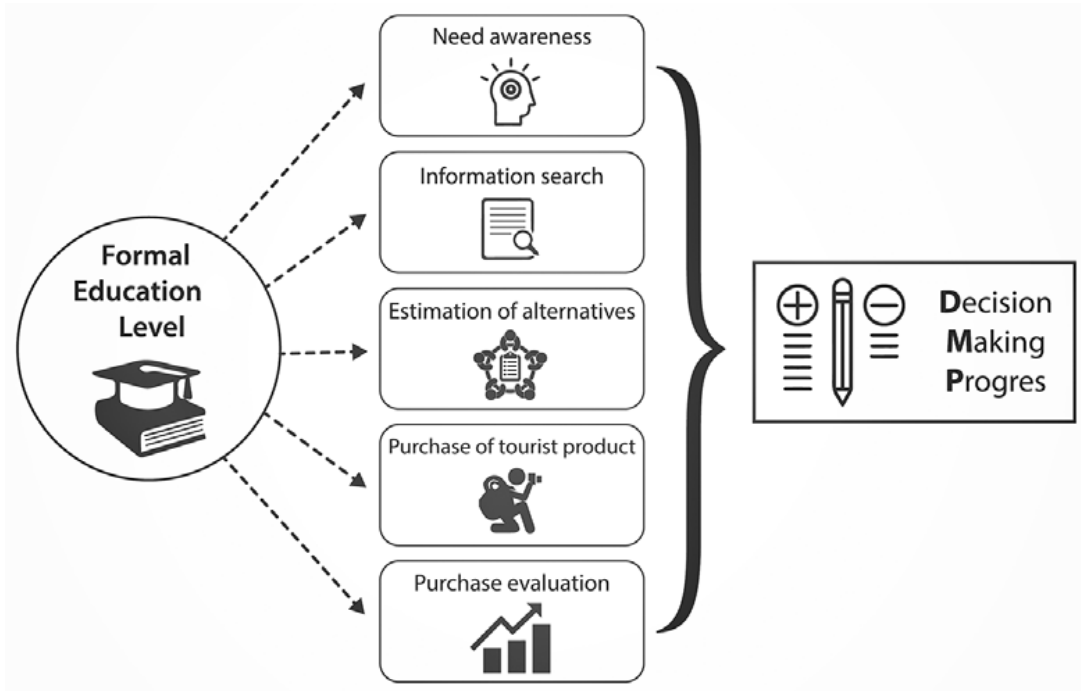

Figure 1. Hypothetical model of research

ist destination, solves his problem, and it involves five phases: need awareness, information search, alternatives estimation, decision about purchasing a tourist product or service and purchasing evaluation (Kotler, Keller, 2006; Mathieson, Wall, 1982). The main hypothesis on which this study is based is:

H1. There is a statistically significant difference among respondents of different education level in all five phases of decision-making process when choosing a tourist destination (Figure 1).

\section{Literature review}

Due to the specificity of the tourism product, primarily its intangibility, customer's information seeking prior to purchase and alternative estimation, is emphasized in tourism industry like in no other sector (Decrop, 2006; Sirakaya, Woodside 2005; Blešić, et al., 2011, McCabe, et al., 2016). It is therefore extremely important to understand the processes and phases of decision making on taking a trip to a particular destination.

There is a wide array of different theories concerning the behaviour of potential tourists when it comes to decision making about a tourist destination. The analysis of the decision-making involves researching into how they choose among different tourist destination offers, as well as processes that precede and are a part of the decision-making itself. Moreover, many of the earlier literature on consumer behavior research focuses on the distribution of gender roles (Filiatrault, Ritchie, 1980; Jenkins, 1978; Nichols, Snepenger, 1988; Blešić, et al., 2014) and cultural influences (Lee, Kalen, 2009). Also the economic and non economic factors influence on decision making (Davies, Downward, 2007; Djeri, et al., 2014). Also very popular are the studies about children's influence over family destination decision making (Kozak, 2010; Labrecque, Rich- ard, 2001; Bronner, Hoog, 2008; Borgeman, Van der Poel, 2006; Foxman, et al., 1989; Howard, Madrigal, 1990; Palan, Wilkes, 1997; Thornton, et al., 1997; Beatty, Talpade, 1994; Nickerson, Jurowski, 2001; Wang, et al., 2004) but also those dealing with the influence of education on consumer behavior on the insurance market (Ioncică, et al., 2012).

The classical concept of prescriptive, analytical everyday decision making (Edwards, 1954; Von Neumann, Morgenstern, 1944) claims that people collect and analyze information, eventually selecting an optimal solution from the range of alternatives (the 'choice set'). They work on it by evaluating the advantages and disadvantages of each possible outcome, choosing the most appropriate ones to achieve their desired objective. Thus, one of the major factors influencing consumer decisions to purchase a product or service is information about the product or service. Information search or information seeking is the process of consulting various sources before making a purchasing decision (Anderek, 2016). Choosing and buying products involves either dependent or independent decisions and thereby a decision-making process. In particular, the literature entails an increasing number of both conceptual and empirical studies over the last two decades concerning decision making in tourism and leisure choices. These studies relate specifically to the influence of internal and external factors (e.g., income, marital status, gender, e-word of mouth, and motivations) on decision making regarding vacations (Hernández-Méndez, et al., 2015; Adzam, et al., 2016; Um, Crompton, 199o; Woodside, Lysonski, 1989; Nichols, Snepenger, 1988). Um and Crompton (1990) were identifing the role of attitudes in an individual's pleasure travel destination choice process. In the mentioned study potential travelers' awareness sets and evoked sets were defined and identified longitu- 
dinally, reflecting progression through their destination choice process.

However, there is little research addressing the influence of education level on the process of decision making concerning the travel destination. The influence of education level in chosing travel destination is mentioned in only one tourism paper (Wong, et al., 2016), and the results revealed that more educated people engage in international travel more often, while those less educated travel within the state more often. Studies dealing with influence of education on travel decision making are not found in this field. This study is basen on the assumption that education level of potential tourists may not only affect their preferences, but also information seeking prior to purchase, the way of decision making, and selection of specific destinations.

\section{Methods and data}

\section{Sample}

The sample consists of 252 respondents whose residence is in Bačka region (the region of Vojvodina/Serbia). There was a slightly higher number of female respondents, and the most frequent age category was 26-35 (36.11\% of respondents). More than half of the sample are married respondents, and they mostly are highly educated. Sample characteristics are shown in Table 1.

\section{Questionnare design}

The research was conducted through a questionnaire which consisted of two parts. The first part of the questionnaire referred to the analysis of social demographic characteristics of the respondents (gender, age, education, montly income and employment status). The second part of the questionnaire consisted of questions referring to all five phases in the decision making process when choosing a tourist destination (see Tables 2, 4, 6, 7, 9). The number of questions differs according to the features of the phases they refer to.

\section{Procedure}

The research was conducted among the population of Bačka region (the region of Vojvodina/Serbia), and the sample which represents the basic span consists of individuals who consume the services of selected travel agents in - Novi Sad (18 agencies), Subotica (6 agencies), Sombor (4 agencies), Backa Topola (3 agencies), and Vrbas (4 agencies) were interviewed over the phone and asked to participate in the research. From the total of 35 travel agencies, 27 participated in the research.

The selected agencies are located in the largest cities and physically are placed on the different parts of the territory of Bačka region in Vojvodina/Serbia. Travel agents sent the questionnaires to the costumers by e-
Table 1. Sample characteristics $(\mathrm{N}=252)$

\begin{tabular}{|c|c|}
\hline Gender & $\%$ \\
\hline Female & 59.92 \\
\hline Male & 40.08 \\
\hline Age & $\%$ \\
\hline $18-25$ & 11.90 \\
\hline $26-35$ & 36.11 \\
\hline $36-45$ & 25.40 \\
\hline $46-55$ & 18.25 \\
\hline $56-65$ & 6.35 \\
\hline over 65 years & 1.99 \\
\hline Level of education & $\%$ \\
\hline Secondary education & 48.41 \\
\hline $\begin{array}{l}\text { Higher and University degree, or Master of } \\
\text { Science degree or PhD }\end{array}$ & 50.79 \\
\hline Other & 0.8 \\
\hline Level of incomes & $\%$ \\
\hline very high - (720 € or more) & 50.40 \\
\hline high - (441 - $719 €)$ & 29.76 \\
\hline medium - $(211-440 €)$ & 11.11 \\
\hline low - (Less than $210 €$ ) & 8.73 \\
\hline Marital status & $\%$ \\
\hline Married & 53.17 \\
\hline Single & 37.70 \\
\hline Divorces & 6.75 \\
\hline Widowed & 2.38 \\
\hline Employment status & $\%$ \\
\hline Employed & 73.02 \\
\hline Unemployed & 26.98 \\
\hline
\end{tabular}

Source: Data obtained by survey research

mail, after their return from the holiday. The sample was random and the survey was conducted from January till December 2012. About 600 questionnaires were sent but only 252 were returned. The questionnaires reflect the tourists opinion upon the process of decision making after selecting a tourist destination (in this case coastal regions). Questionnaires have been analyzed according to answers of 252 participants, but what lacks is the estimation of frequency variation within different phases. Indicators for all five phases of decisionmaking process were identified in order to measure the influence of the level of education on different phases of decision-making process when purchasing a tourist product. Indicators are described in precisely determined phases of decision-making process.

\section{Data Analysis}

Univariate and multivariate methods have been used in the mathematical-statistical procedures of data processing: multivariate analysis (MANOVA), dis- 
criminative analysis, coefficient of discrimination (Hadžić, 1989).

Application of methods, based on obtained measures, throws a new light on research. The features defining specificity of groups and also those to be excluded from further revealed research by calculating the discrimination coefficient.

Multivariate analysis of variance (MANOVA) is a generalized form of univariate analysis of variance (ANOVA). In order to address the statistical differences between and in the tested groups Wilks' Lambda $(\chi)$ and Roy's Largest Root (R) tests were used. The features defining specificity of groups and also those to be excluded from further research have been revealed by calculating the discrimination coefficient (Pallant, 2013).

Discrimination coefficient is a correlation coefficient between the results obtained from a single question and from the whole questionnaire. This parameter may have values between +1 and -1 and is calculated as follows:

$$
D C=\operatorname{Sum}(x y) /(N \cdot s x \cdot s y)
$$

Sum $(x y)$ denotes a sum of the deviation products for the results of single questions and overall questionnaire results, $\mathrm{N}$ is a number of responds to a single question obtained from the respondents, sx is a standard deviation of a partial sum for that question and sy is a standard deviation of the overall questionnaire results. Significant differences between the variables are marked with sig. For the value of sig. more 0.05, there is no difference between the observed groups (place of residence, age structure, level of education attained, etc.) while for the values of sig. less than 0.05 there is a significant variation between the observed groups (Pallant, 2013).

\section{Results}

\section{Analysis of the first phase of decision making - need awareness}

In this part of the research we aim to confirm or reject the claim of the existence of significant differences between opinions and attitudes of potential tourists with different education level (secondary school education, higher and university degree, or Master of Science degree or $\mathrm{PhD}$ ) in relation to the need awareness (10 indicators that define the first phase (n)) as a first phase in the decision making process about the tourist destination choice.

A total of 65 variables were used to analyze the first phase - need awareness, which we grouped into seven categories (Table 2).
Table 2. Factors of the first phase of decision making need awareness

\begin{tabular}{|l|c|}
\hline Factor & Code \\
\hline A way of spending free time & A1 \\
\hline The preferred forms of tourist travel & A2 \\
\hline Way of recognizing the need to travel & A3 \\
\hline $\begin{array}{l}\text { Reasons why potential tourists decide to } \\
\text { travel }\end{array}$ & A4 \\
\hline $\begin{array}{l}\text { Presence of sociological factors when } \\
\text { making the decision to travel }\end{array}$ & A5 \\
\hline $\begin{array}{l}\text { Presence of geographical factors when } \\
\text { making the decision to travel }\end{array}$ & A6 \\
\hline $\begin{array}{l}\text { Presence of needs that would be first } \\
\text { satisfied by potential tourists if they had } \\
\text { unlimited financial resources available }\end{array}$ & A7 \\
\hline
\end{tabular}

Firstly, MANOVA analysis was conducted to check whether there are significant differences in the phase 1 (need awareness) in relation to the education level.

The results of the MANOVA analysis $(\mathrm{F}=0.002$; $\mathrm{p}<1.000$ ), indicate that there is no difference between the responses of potential tourists to the questions of the first phase of the decision making process on the tourist destination choice.

Wilks' Lambda and Roy's Largest Root tests were used to test the existence of statistical differences between and in the tested groups. Tests proved statistical significance in the several categories ${ }^{1}$ :

The analysis of discrimination coefficient (Table 3) has shown that it is the highest with the presence of ways to spend free time ( $\mathrm{A} 1)$ (o.111), preferred form of tourist travel (A2) (o.103) and sociological factors presence at decision making process about travelling (A5) (0.076).

Table 3. Values of discrimination coefficient for need awareness indicator regarding level of education of a respondent

\begin{tabular}{|c|c|}
\hline Indicator & Discrimination Coefficient \\
\hline A1 & 0.111 \\
\hline A2 & 0.103 \\
\hline A3 & 0.076 \\
\hline A4 & 0.066 \\
\hline A5 & 0.058 \\
\hline A6 & 0.053 \\
\hline A7 & 0.028 \\
\hline
\end{tabular}

Source: Data obtained by survey research

1 A1 $(\chi=0.353, \mathrm{R}=0.377, \mathrm{~F}=38.739$, sig.=0.000), A2 $(\chi=0.165$, $\mathrm{R}=0.167, \mathrm{~F}=6.742$, sig.=0.010), $\mathrm{A}_{3}(\chi=0.152, \mathrm{R}=0.153, \mathrm{~F}=5.634$, sig.=0.018), A4 $(\chi=0.355, R=0.380, F=39.445$, sig. $=0.000), A_{5}$ $(\chi=0.165, R=0.168, F=6.759$, sig. $=0.010), A 6(X=0.217, R=0.222$, $\mathrm{F}=12.127$, sig. $=0.001$ ) 
Way of spending free time (A1) is determined with five variables: no answer, active, passive, with entertainment, by computer, other, while the preferred tourist travel forms $\left(\mathrm{A}_{2}\right)$ are determined by nine variables: wellness, sea, cruises, mountains, travels, village, safari, sport related travels, cultural property, religious tourism.

\section{Analysis of the second phase decision making process - information search}

In this part of the research the aim was to confirm or reject the claim of the existence of significant differences between opinions and attitudes of potential tourists having different education level (secondary school education, higher and university degree, or Master of Science degree or $\mathrm{PhD}$ ) in relation to the information search (11 indicators that define the first phase (n)) as a second phase in the decision making process about the choice of tourist a destination.

Total of 53 variables were used to analyze the second phase - searching for information, which we grouped into 11 categories (Table 4).

Table 4. Factors of the second phase of decision making information search

\begin{tabular}{|l|c|}
\hline Factor & Code \\
\hline $\begin{array}{l}\text { Influence of already possessed information } \\
\text { about the tourist destination on the } \\
\text { intensity of collecting additional } \\
\text { information }\end{array}$ & inf1 \\
\hline $\begin{array}{l}\text { Influence of satisfaction with services } \\
\text { rendered on the intensity of information } \\
\text { search about a tourist destination }\end{array}$ & inf2 \\
\hline $\begin{array}{l}\text { The most trustworthy sources of } \\
\text { information on tourist destination }\end{array}$ & inf3 \\
\hline $\begin{array}{l}\text { Marketing source types of highest influence } \\
\text { in the process of information search }\end{array}$ & inf4 \\
\hline $\begin{array}{l}\text { The types of personal sources that have } \\
\text { the greatest influence in the process of } \\
\text { gathering information }\end{array}$ & inf5 \\
\hline $\begin{array}{l}\text { Types of neutral sources that have the } \\
\text { greatest influence in the process of } \\
\text { gathering information }\end{array}$ & inf6 \\
\hline $\begin{array}{l}\text { Loyalty influence on the intensity gathering } \\
\text { information about the tourist destination }\end{array}$ & inf7 \\
\hline $\begin{array}{l}\text { Discount influence offers on the intensity } \\
\text { of information by searching about tourist } \\
\text { destination }\end{array}$ & inf8 \\
\hline $\begin{array}{l}\text { The influence of urgent selection and } \\
\text { reaching the decision of travelling on the } \\
\text { intensity of collecting information about } \\
\text { travelling }\end{array}$ & inf11 \\
\hline $\begin{array}{l}\text { Ways of collecting information about travel } \\
\text { arrangements }\end{array}$ & $\begin{array}{l}\text { Degree of satisfaction with the amount and } \\
\text { quality of information about tourist offer }\end{array}$ \\
\hline
\end{tabular}

Based on the results of the MANOVA analysis $(\mathrm{F}=2.217 ; \mathrm{p}<0.00)$, it is noticeable that there is a significant difference between the responses of potential tourists to the questions of the second phase of the decision making process on the choice of tourist destinations in relation to the level of education.

Values of discrimination coefficient (Table 5) are the highest for: The most trustworthy sources of information on tourist destination (inf 3 ) (which is determined with five variables: marketing sources, personal sources, opinions of family and friends, neutral sources and other), and The types of personal sources that have the greatest influence in the process of search for information (inf5) which is defined by four variables: experience, attitudes; opinions and experiences of the closest people opinion of a respected person.

Table 5. Values of discrimination coefficient for information search indicator regarding level of education of a respondent

\begin{tabular}{|c|c|}
\hline Indicator & Discrimination Coefficient \\
\hline (inf3) & 0.072 \\
\hline (inf5) & 0.039 \\
\hline (inf7) & 0.036 \\
\hline (inf4) & 0.035 \\
\hline (inf9) & 0.028 \\
\hline (inf11) & 0.024 \\
\hline (inf2) & 0.020 \\
\hline (inf10) & 0.014 \\
\hline (inf6) & 0.012 \\
\hline (inf8) & 0.009 \\
\hline (inf1) & 0.003 \\
\hline
\end{tabular}

Source: Data obtained by survey research

Wilks' Lambda and Roy's Largest Root tests were used to test the existence of statistical differences between and in the tested groups. Tests proved statistical significance in the all factors ${ }^{2}$.

\section{Analysis of the third phase decision making process - estimation of alternatives}

In this part of the research the aim was to confirm or reject the claim of the existence of significant differences between opinions and attitudes of potential tourists with different education level (secondary school education, higher and university degree, or

2 inf1 $(\chi=0.231, \mathrm{R}=0.238, \mathrm{~F}=14.233$, sig.=0.00o), inf2 $(\chi=0.167$, $\mathrm{R}=0.170, \mathrm{~F}=7.044$, sig.=0.008), inf $3(\chi=0.238, \mathrm{R}=0.245, \mathrm{~F}=15.128$ sig.=0.000), inf4 ( $\chi=0.200, \mathrm{R}=0.205, \mathrm{~F}=10.391, \quad$ sig.=0.002), inf5 $(\chi=0.244, \mathrm{R}=0.251, \mathrm{~F}=16.046$, sig. $=0.000)$, inf $6(\chi=0.236$, $\mathrm{R}=0.243, \mathrm{~F}=14.941$, sig.=0.00o), inf $7(\chi=0.231, \mathrm{R}=0.237, \mathrm{~F}=14.172$, sig.=0.00o), inf $8(\chi=0.175, \mathrm{R}=0.178, \mathrm{~F}=7.753$ sig.=0.006), inf9 $(\chi=0.192, \mathrm{R}=0.196, \mathrm{~F}=9.481$, sig. $=0.002)$, inf1o $(\chi=0.120, \mathrm{R}=0.120$, $\mathrm{F}=3.500$, sig. $=0.059)$, inf11 $(\chi=0.187, \mathrm{R}=0.190, \mathrm{~F}=8.936$, sig. $=0.003)$. 
Master of Science degree or $\mathrm{PhD}$ ) in relation to the estimation of alternatives as a third phase in the decision making process about the choice of a tourist destination.

A total of 13 variables were used to analyze the third phase-estimation of alternatives, which are grouped into 2 categories (Table 6).

Table 6. Factors of the third phase of decision making estimation of alternatives

\begin{tabular}{|l|c|}
\hline Factor & Code \\
\hline $\begin{array}{l}\text { Decision making forms in the process of } \\
\text { tourist destination selection }\end{array}$ & E11 \\
\hline $\begin{array}{l}\text { The most significant factors in estimation of } \\
\text { tourist destination alternatives }\end{array}$ & E21 \\
\hline
\end{tabular}

The results $(\mathrm{F}=7.780, \mathrm{p}<0.000)$ show that there is a significant difference between the responses of potential tourists to the questions of the third phase of the decision making process on the tourist destination choices in relation to the education level.

Wilks' Lambda and Roy's Largest Root tests were used to test the existence of statistical differences between and in the tested groups. Tests proved statistical significance ${ }^{3}$. Discrimination coefficient proved to be the highest with the estimation of alternatives (E21) (0.061) and then with the forms of decision making in the process of tourist destination selection (El1) (0.010).

The most important factor alternative estimations of tourist destinations (E21) and decision making forms in the process of tourist destination selection (El1) are determined with ten variables. Seven of these ten relate to estimation of alternatives of tourist destinations (E21): quality, image, prestige (E21-1), preferences, expectations, attitudes (E21-2), courtesy and the atmosphere in the selling point (E21-3), lifestyle, opinions of others (E21-4), price, payment options (E21-5) previous experience (E21-6), all inclusive arrangements (E21-8), and the other three forms of decision making in tourist destination process selection (El1): rapidly based on intuition (El1-1); difficult estimating all the alternatives (El1-2), by family and friend consultations (El1-3).

\section{Analysis of the fourth phase decision making process - purchase of tourist product}

In this part of the research the goal was to confirm or reject the claim of the existence of significant differences between opinions and attitudes of potential tourists with different education level (secondary school education, higher and university degree, or

$3 \operatorname{El}_{1}(\chi=0.118, R=0.118, \mathrm{~F}=3.352$, sig. $=0.065) ; \mathrm{E}_{21}(\chi=0.225, R=0.231$, $F=13.355$, sig.=0.00o).
Master of Science degree or $\mathrm{PhD}$ ) in relation to the purchase of a tourist product as a fourth phase in the decision making process about the tourist destination choice.

A total of 32 variables were used to analyze the fourth phase - decision making by purchase of a tourist product, which are grouped into 6 categories.

Table 7. Factors of the forth phase of decision making purchase of tourist product

\begin{tabular}{|l|c|}
\hline Factor & Code \\
\hline $\begin{array}{l}\text { The influence factor on deciding on the } \\
\text { purchase of a particular tourist product }\end{array}$ & P1 \\
\hline The selling point of tourist arrangements & P2 \\
\hline The way to purchase tourist arrangements & P3 \\
\hline $\begin{array}{l}\text { The price and payment option influences on } \\
\text { the purchase of a tourist product }\end{array}$ & P4 \\
\hline Purchase preferred form of tourist product & P5 \\
\hline $\begin{array}{l}\text { Unpredicted situation influences at the } \\
\text { selling point on reaching the final decision }\end{array}$ & P6 \\
\hline
\end{tabular}

The results showed that there is a significant difference $(F=7.446 ; p<0.000)$ between the responses of potential tourists to the questions of the fourth phase of the decision making process on the choice of tourist destinations in relation to the education level.

Wilks' Lambda and Roy's Largest Root tests were used to test the existence of statistical differences between and in the tested groups. Tests proved statistical significance ${ }^{4}$ Discrimination coefficient analyses (Table 8) has shown that it is the highest with the price and payment options' influence on the purchase of a tourist product $\left(\mathrm{P}_{4}\right)(\mathrm{o.065})$, influence factor of deciding on the purchase/purchase decision of a particular tourist product $(\mathrm{P} 1)(0.045)$ and by selling point of tourist arrangements $\left(\mathrm{P}_{2}\right)(0.043)$.

Table 8. Values of discrimination coefficient for purchase of a tourist product indicator regarding education level of a respondent

\begin{tabular}{|c|c|}
\hline Indicator & Discrimination Coefficient \\
\hline (P4) & 0.065 \\
\hline (P1) & 0.045 \\
\hline (P2) & 0.043 \\
\hline (P6) & 0.019 \\
\hline (P5) & 0.013 \\
\hline (P3) & 0.001 \\
\hline
\end{tabular}

Source: Data obtained by survey research

$4 \quad \mathrm{P}_{1} \quad(\chi=0.226, \mathrm{R}=0.232, \quad \mathrm{~F}=13.357, \quad$ sig. $=0.000), \quad \mathrm{P} 2 \quad(\chi=0.189$, $\mathrm{R}=0.192, \mathrm{~F}=9.012$, sig. $=0.003), \mathrm{P}_{3}(\chi=0.003, \mathrm{R}=0.003, \mathrm{~F}=0.003$, sig.=0.913), $P_{4}(\chi=0.226, R=0.232, F=13.350$, sig. $=0.000), P_{5}$ $(X=0.124, R=0.125, F=3.708$, sig. $=0.057), P 6(X=0.146, R=0.148$, $\mathrm{F}=5.241$, sig. $=0.022$ ) 
The price and payment options influence on the purchase of a tourist product $\left(\mathrm{P}_{4}\right)$ and the influence factor on deciding on the purchase of a particular tourist product $\left(\mathrm{P}_{1}\right)$ in relation to the education level of potential tourists are determined with thirteen variables. Variables used for measuring the price and payment options influence on the purchase of a tourist product are: Not at all, Small, Somewhat, Significant, Large influence. Variables used for measuring the influence factor on deciding on the purchase of a particular tourist product $\left(\mathrm{P}_{1}\right)$ are: No answer, Personal assessment, Preferred product, Attitudes of others, Unexpected events, Inflation and Supplements, Unstable situation, Other.

\section{Analysis of the fifth phase - purchase evaluation}

In this step, the research indented to explore if there are significant differences between opinions and attitudes of potential tourists with different education level (secondary school education, higher and university degree, or Master of Science degree or $\mathrm{PhD}$ ) in relation to the purchase evaluation as a fifth phase in the decision making process about tourist destination chioce.

A total of 51 variables were used to analyze the fifth phase - post purchase evaluation, which are grouped into 10 categories.

Table 9. Factors of the fifth phase of decision making purchase evaluation

\begin{tabular}{|l|c|}
\hline Factor & Code \\
\hline $\begin{array}{l}\text { Satisfaction influence on repeated purchase } \\
\text { with the same travel agent }\end{array}$ & PE1 \\
\hline Tourist travel frequencies & PE2 \\
\hline $\begin{array}{l}\text { The amount of money spent on tourist } \\
\text { travel from the annual income }\end{array}$ & PE3 \\
\hline Decision making results of tourist travels & PE4 \\
\hline Tourism priority forms & PE5 \\
\hline Traveling in season & PE6 \\
\hline Traveling in the preseason & PE7 \\
\hline Traveling in the low season & PE8 \\
\hline $\begin{array}{l}\text { Satisfaction infulence with the expected } \\
\text { service quality }\end{array}$ & PE9 \\
\hline $\begin{array}{l}\text { The way of expressing dissatisfaction with } \\
\text { the expected level of tourism services }\end{array}$ & PE10 \\
\hline
\end{tabular}

Based on the results of MANOVA analysis $(\mathrm{F}=10.047 ; \mathrm{p}<0.00)$, it is noticeable that there is a significant difference between the responses of potential tourists to the questions of the fifth phase of the decision making process on the choice of tourist destinations in relation to education level.

Wilks' Lambda and Roy's Largest Root tests were used to test the existence of statistical differences be- tween and in the tested groups. Tests proved statistical significance ${ }^{5}$.

The highest discrimination coefficient analyses ( $\mathrm{Ta}$ ble 10) has the frequency of tourist travels ( $\left.\mathrm{PE}_{2}\right)$ (0.074), the priority forms of tourism $\left(\mathrm{PE}_{5}\right)$ (o.048).

Table 10. Values of discrimination coefficient for purchase evaluation indicator regarding education level of a respondent

\begin{tabular}{|c|c|}
\hline Indicator & Discrimination coefficient \\
\hline (PE2) & 0.074 \\
\hline (PE5) & 0.048 \\
\hline (PE4) & 0.043 \\
\hline (PE8) & 0.042 \\
\hline (PE6) & 0.030 \\
\hline (PE10) & 0.029 \\
\hline (PE7) & 0.020 \\
\hline (PE1) & 0.017 \\
\hline (PE3) & 0.005 \\
\hline (PE9) & 0.005 \\
\hline
\end{tabular}

Source: Data obtained by survey research

Tourist travel frequency ( $\left.\mathrm{PE}_{2}\right)$ is determined by the following variables: No answer, Continuous, Occasional, Other. For the analysis of the priority forms of tourism ( $\mathrm{PE}_{2}$ ): Continuous, Occasionally, Other. For the analysis of priority forms of tourism (PE5): Summer holidays at sea, mountain winter holidays, Vacations in ecological environment, Extreme sports; Active holiday in the countryside, Exotic travel, Cruises, Short travels, Other.

\section{Discussion and conclusion}

From the practitioner point of view, distinguishing and meeting of potential tourist needs is extremely important. The ability to determine the influence of education level of potential tourists at the final purchasing decisions is an important point for marketing planning and shaping marketing strategies. A possible research suggestion may include the development of marketing programs to attract the attention of both groups of tourists: those with secondary education and those with higher education in order to make their decision-making process easier.

\footnotetext{
$5 \quad$ PE1 $(\chi=0.136, \quad R=0.138, \quad F=4.517, \quad$ sig. $=0.033), \quad P E 2 \quad(\chi=0.337$, $\mathrm{R}=0.358, \mathrm{~F}=34.294$, sig.=0.00o), $\mathrm{PE}_{3}(\chi=0.161, \mathrm{R}=0.164, \mathrm{~F}=6.431$, sig.=0.011), $\mathrm{PE}_{4}(\chi=0.182, \mathrm{R}=0.185, \mathrm{~F}=8.289$, sig.=0.004), $\mathrm{PE} 5$ $(\chi=0.276, \quad \mathrm{R}=0.287, \mathrm{~F}=21.065$, sig. $=0.000)$, PE6 $\quad(\chi=0.094$, $\mathrm{R}=0.094, \mathrm{~F}=2.096$, sig. $=\mathbf{0 . 1 4 5}), \mathrm{PE} 7(\chi=0.325, \mathrm{R}=0.344, \mathrm{~F}=31.387$, sig.=0.00o), PE8 ( $\chi=0.292, \mathrm{R}=0.305, \mathrm{~F}=2.998$, sig.=0.000), PE9 $(X=0.081, R=0.081, F=1.539$, sig. $=$ o.213 $), P E 10(X=0.257, R=0.266$, $\mathrm{F}=17.824$, sig. $=0.000)$.
} 
The main hypothesis of this research was that there is a significant difference considering education level of the tourists in all five phases of decision makingprocess when choosing a tourist destination. However, MANOVA results have shown that there are no differences in the first phase of the decision-making process (need awareness, $\mathrm{F}=0.002$, sig. $=1.000$ ) regarding education level of the tourists. This means that nevertheless of their educational level, all respondents have similar factors affecting their decisions to travel, as well as similar needs and motives. The difference between them occurs when they go further in the process of thinking how to satisfy those needs and motives.

Thus, in other four phases (information search, $\mathrm{F}=2.717$, sig.=0.00o; estimation of alternatives $\mathrm{F}=$, sig. $=0.000$; purchase of the product $\mathrm{F}=7.446$, sig. $=0.000$; and purchase evaluation $\mathrm{F}=10.477$, sig. $=0.000$ ) the statistical differences were observed.

Additional analysis showed that respondents with secondary education in the first phase - need awareness, preferred rural tourism. The most common reason for tourist travel is seeing new scenery and getting to know new cultures. Respondents with higher education, in the same phase, preferred safari tourism. Getting to know new landscapes and cultures are the most common reasons for tourist travel. In the detailed analysis of psychological factors, pleasure that travel can provide stands out compared to sociological habits and expectations and economic propaganda messages in the media (TV commercials).

For respondents with secondary education, in the second phase - information search, the information they already have does not affect the new information search about the tourist destination. This may mean that they are more open to new information and that it is easier to shape their opinion by media or other means of promotion compared to respondents with higher education. The results show that even the loyalty to travel agency does not affect the intensity of information search. However, they rely on the wordof-mouth promotion, as the most reliable source of information is the family and opinion of friends. The urgent selection has a significant affect while discount offer has a decisive influence, meaning that different promotional offers such as last minute travel offers could be very attractive to this segment of tourists. For respondents with higher education, previously possessed information and satisfaction with services rendered only slightly affect the intensity of the new information search, meaning that they rely on their personal experience and previous knowledge more than people with secondary school. This could be because they are more self-confident due to their longer education and they trust information theiy already have. For respondents with higher education the preferred marketing source is consumer pamphlets, while of personal sources the most valuable are their attitudes and opinions about the tourist destination, which is in the line with previous findings.

In the third phase - the estimation of alternatives, for the respondents with secondary education the decision on the choice of a tourist destination is made in consultation with family and friends. This could mean that they do not rely so much on information they have and their own judgments, but they seek help from the close people. When evaluating alternative tourist destinations the greatest importance is placed on the all inclusive arrangements, courtesy of tourism workers and atmosphere at the selling point which indicates that people with secondary school expect high level of "pampering" at travel destination and high quality experience. On the other hand, in case of the respondents with higher education, the decision on the selection of a tourist destination is difficult to make while assessing all the alternatives. The most important factors of assessment are preferences, expectations and attitudes about tourist destinations meaning they rely on their own judgments. The results also indicate that they perfer individual arrangements, which are tailored to satisfy their specific desires and needs, which differes from people with secondary school who prefer all inclusive packages. Although there were no studies connecting education and decision making, it is interesting to mention that some similar studies found that people who are travelling with family members tend to place more emphasis on facilities and safety than those who are travelling alone (Lai, Graefe, 200o). It is also suggested that people are more willing to take a package tour for their first-time international pleasure travel, and normally place a higher value on word-of-mouth communication than more experienced repeat travellers (Wong, Kwong, 2004). Thus it is interesting for future research to include these variables and to explore their possible mediating effect on relationship between education and decision making.

In the fourth phase-purchase of a tourist product, for the respondents with secondary education, it can be concluded that travel packages are often bought at travel agencies where friends or relatives work. This is in the line with the finding that they rely mostly on their firends and family's opinion while choosing between travel alternatives (also, at purchase all alternatives are evaluated). Price and payment options have a large influence on the purchase of a tourist product, which is also connected with the finding that they opt for travel discounts. Unexpected events have the greatest impact on respondents with higher education. This could be connected with the nature of their 
job which requires a lot of unexpected travelling. Exclusive agencies are usually chosen and purchasing is done at once, meaning they trust in agencies which already became a brend on the market. Price and payment options do not affect the choice, which may be explained by the fact that people with higher education also earn more money. As they rely on their personal judgments, personal shopping is preferred.

In the fifth phase - post purchase evaluation, for the respondents with secondary education satisfaction has a small influence on the purchase at the same travel agency, meaning they like to experiment with travel agencies and they may opt for those that offer the cheapest itineraries at the moment. They mostly travel in preseason because of less overbooked capacities and in post season due to lower cost of arrangements. Satisfaction with the expected quality of service rendered results in recommendations to friends and acquaintances, as they also rely on their recommendation while deciding where to travel. Dissatisfaction with the quality of service is expressed through angry silence, which indicates that they are not prone to complaining and spreading the negative word of mouth. In case of the respondents with higher education it was found that satisfaction only slightly affects the repeated purchase. They travel regularly and continuously, and spend relatively a lot of money (more than one third of annual income). This may be explained by their higher income compared to people with secondary education, but also travelling may be a part of their job description. What is different compared to people with secondary education, is that their satisfaction with quality of service increases loyalty to the travel agency and result in the repeated purchase, meaning that they prefer quality over price and stay loyal customer even some agencies have cheaper offer.

On balance, the results of this research are of particular importance for improving business in terms of managing the development of new and adaptation of existing tourism products, according to the preferences of potential tourists. Moreover, undarstanding the way that two analyzed groups behave while chosing travel destinations can be of great importance for shaping the marketing activities and travel promotional tools in order to attract each of them. These findings could also help travel agents to attract the loyal customers and shape their communication strategies, which is important for business success of every company on the tourist market. One of the main limitations of the study was a lengthy questionnaire which prolonged the process of collecting the adaquate study sample. Moreover, the survey focused only on people choosing costal regions as tourist destination, so the future reseach could also include diverse destinations such as cities, mountains, spas etc. in order to check if the same results would be obtained. Future research can also analyze how other socio-demographic characteristics such as income, age, marital status affect the decision-making process when choosing a tourist destination.

\section{References}

Adzam, A., Aziz, H., Syazwani, F., Kelvin, Y. 2016. Gender Differences in Tourism Destination Choice in Malaysia. 3rd Kanita postgraduate International conference on gender studies, November $16-17$, University Sains, Malaysia.

Andereck, K. L. 2016. Tourism Product Involvement and Information Search. Tourism Travel and Research Association: Advancing Tourism Research Globally. $47^{\text {th }}$ Annual International Conference of the Travel and Tourism Research Association, June 15-17, Vail, Colorado.

Beatty, S. E., Talpade, S. 1994. Adolescent influence in family decision making: a replication with extension. Journal of Consumer Research, 21, 2, 332-341.

Borgeman, B., Van der Poel, H. 2006. The role of routines in the vacation decision-making process of Dutch vacationers, Tourism Management, 27, 4, 707-720.

Blešić, I., Tešanović, D., Psodorov, Đ. 2011. Consumer satisfaction and quality management in the hospitality industry in south-east Europe. African Journal of Business and Management, 5, 4, 1388.

Blešić, I., Popov-Raljić, J., Uravić, L., Stankov, U., Đeri, L., Pantelić, M., Armenski, T. 2014. An importanceperformance analysis of service quality in spa hotels, Economich Research, 27, 1, 483-495.

Bronner, F., De Hoog, R. 2008. Agreement and disagreement in family vacation decision-making, Tourism Management, 29, 5, 967-979.

Ćopić, S., Đorđević, J., Lukić, T., Stojanović, V., Đukičin, S., Besermenji, S., Tumarić, A. 2014. Transformation of Industrial Heritage-an Example of Tourism Industry Development in the Ruhr Area (Germany). Geographica Pannonica, 18, 2, 4350.

Davies, B., Downvard, P. 2007. Exploring price and non-price decision making in the UK package tour industry: Insights from small-scale travel agents and tour operators, Tourism Management, 28, 5, 1236-1261.

Decrop, A. 2006. Vacation Decision Making. Oxon, CABI Publishing, Wallingford.

Djeri, L., Plavša, J., Čerović, S. 2007. Analysis of Potential Tourists' Behaviour in the Process of Deciding Upon a Tourist Destination Based on a Survey Conducted in Backa Region, Geographica Pannonica, 11, 1, 70-76. 
Djeri, L., Armenski, T., Jovanović, T., Dragin, A. 2014. How income influences the choice of tourism destination?. Acta Oeconomica, 64, 2, 219-237.

Edwards, W. 1954. The theory of decision-making, Psychological Bulletin, 51, 4, 380.

Filiatrault, P., Ritchie, J. 1980. Joint purchasing decisions: a comparison of influence structure in family and couple decisions making units, Journal of Consumer Research, 7, 2, 131-140.

Foxman, E., Tansuhaj, P., Ekstrom, K. 1989. Family members' perceptions of adolescents' influence in family decision making, Journal of Consumer Research, 15, 4, 482-491.

Hadžić, O. 1989. Numerical and statistical methods in the anaysis of experimental data. Faculty of Science, Novi Sad (in Serbian)

Hernández-Méndez J., Muñoz-Leiva F., SánchezFernánde J. 2015. The influence of e-word-of-mouth on travel decision-making: consumer profiles. Journal Current Issues in Tourism, 18, 11, 1001-1021.

Howard, D., Madrigal, R. 1990. Who makes the decision: the parent or the child? The perceived influence of parents and children on the purchase of recreation services, Journal of Leisure Research, 22, 3, 244.

Ioncică, M., Petrescu, E. C., Ioncică, D., Constantines$\mathrm{cu}, \mathrm{M} .2012$. The role of education on consumer behavior on the insurance market. Procedia-Social and Behavioral Sciences, 46, 4154-4158.

Jenkins, R. 1978. Family vacation decision making. Journal of Travel Research, 16, 4, 2-7.

Karl M. 2016. Risk and Uncertainty in Travel Decision-Making. Journal of Travel Research (first published online: November 19, 2016),1-18, DOI: 10.1177/0047287516678337

Kasagranda A., Rajčáková, E., Vystoupil, J. 2016. Urban tourism in Slovakia-its quantification, spatial differentiation and typification. Geographica Pannonica, 20, 2, 114-126.

Kotler, P., Keller, K. 2006. Marketing management. Prentice-Hall, $12^{\text {th }}$ ed, Upper Saddle River, NJ.

Kozak, M. 2010. Holiday taking decisions - The role of spouses, Tourism Management, 31, 4, 489-494.

Labrecque, J., Ricard, L. 2001. Children's influence on family decision-making: a restaurant study, Journal of Business Research, 54, 2, 173-176.

Lee, J.A., Kacen, J. J. 2008. Cultural influences on consumer satisfaction with impulse and planned purchase decisions, Journal of Business Research, 61, 3, 265-272.
Mathieson, A., Wall, G. 1982. Tourism, economic, physical and social impacts. Longman, London.

McCabe, S., Li, C., Chen, Z. 2016. Time for a radical reappraisal of tourist decision making? Towards a new conceptual model. Journal of Travel Research, 55, 1, 3-15.

Nichols, C., Snepenger, D. 1988. Family decision making and tourism behavior and attitudes. Journal of Travel Research, 26, 4, 2-6.

Nickerson, N., P. Jurowski, C., 2001. The influence of children on vacation travel patterns. Journal of $\mathrm{Va}$ cation Marketing, 7, 1, 19-30.

Palan, K., Wilkes, R. 1997. Adolescent-parent interaction in family decision making. Journal of Consumer Research, 24, 2, 159-169.

Pallant, J. 2013. SPSS survival manual. McGraw-Hill Education, UK.

Sirakaya, E., Woodside, A. 2005. Building and testing theories of decision making by travelers. Tourism Management, 26, 6, 815-832.

Smallman, C., Moore, K. 2010. Process studies of tourists' decision-making. Annals of Tourism Research, 37, 2, 397-422.

Thornton, P., Shaw, G., Williams, A. 1997. Tourist group holiday decision-making and behavior: the influence of children. Tourism Management, 18, 2, 287-297.

Von Neumann, J., Morgenstern, O. 1944. Theory of games and economic behaviour. Princeton University Press, Princeton, NJ

Wang, K., Hsieh, A., Yeh, Y., Tsai, C. 2004. Who is the decision-maker: the parents or the child in group package tours?. Tourism Management, 25, 2, 183-194.

Wong, C. K. S., Kwong, W. Y. Y. 2004. Outbound tourists' selection criteria for choosing all-inclusive package tours. Tourism management, 25, 5, 581-592.

Wong, I. A., Law, R., Zhao, X. 2016. When and Where to Travel? A Longitudinal Multilevel Investigation on Destination Choice and Demand. Journal of Travel Research (first published online: September 29, 2016), 1-13. DOI: 10.1177/0047287516670269

Woodside, A., Lysonski, A. 1989. A general model of traveler destination choice. Journal of Travel Research, 27, 1, 8-14.

Um, S., and Crompton, J. L. 1990. Attitude determinants in tourism destination choice. Annals of Tourism Research, 17, 3, 432-448. 